\title{
THE EMPLOYEE TRAINING AND DEVELOPMENT IN MULTI NATIONAL CORPORATIONS
}

\author{
Dr. C. K. GOMATHY ${ }^{1}$, CHANDRAMOULI SARAVAN SOWRI ${ }^{2}$, CHADA SESHA SAI ISWARYA \\ BALARAM $^{3}$, L.M.ARAVIND ${ }^{4}$ \\ ${ }^{1}$ Assistant Professor, Department of Computer Science and Engineering, SCSVMV, Kanchipuram \\ ${ }^{2}$ Student, Department of Information technology, SCSVMV, Kanchipuram \\ ${ }^{3}$ Student, Department of Information technology, SCSVMV, Kanchipuram \\ ${ }^{4}$ Student, Department of Information technology, SCSVMV, Kanchipuram
}

\begin{abstract}
:
Training and development is significant a part of the human resource development. It will be assuming ever important role in wake of the development of knowledge domain which has resulted in increasing competition, rise in customer's belief of quality and repair along with a subsequent got to lower costs. It is also become more vital worldwide so as to organize workers for brand spanking new jobs. A multinational corporation (MNC) has services other assets in a minimum of one country aside from its home country such companies possess offices and/or factories in numerous countries and normally have a centralized head office where they coordinate world-wide super vision. Very large multinationals have budgets that larger than those of the many small nations. Training and development is important aspect in every organization increase in competitiveness and advancement of technology leads need for training and development.
\end{abstract}

Keywords: Employees Training \& Development, MNC, Human Resource Development.

\section{I.INTRODUCTION:}

A multinational corporation (MNC) has services other assets in a minimum of one country aside from its host country. Such companies possess offices and/or factories in numerous countries and normally have a centralized head office where they coordinate world-wide supervision. Very large multinationals have budgets that larger than those of the many small nations. The need for Training and Development Before we are saying that technology is especially liable for increased necessity of coaching inputs to employees, it's essential to know or know that there are many factors too that contribute to the latter.Training also can be necessary for the individual improvement and progress of the worker, which inspires him to figure for a particular organization aside from just money. We also require training upgrade employees of the market trends, the change within the employment policies and other things. The need for Training and Development is must the two factors that contribute to the increased must training and development in organizations:

Change: The word change encapsulates almost anything. It is one of the biggest factors that be a cause of the need of training and development. There is certainly the very fact is that a particular relationship between the Change leads to the necessity of training and development and training and development leads to personal and organizational change, and the cycle goes on and on. More specifically it's the technology that's driving the need; changing the way how businesses function, compete and deliver. 
Development: it's again one the strong reasons for training and development becoming all the more significant. Money is not the sole motivator at work and this is especially very true for the 21 st century. People who work with organizations seek more than just employment out of their work; they look at natural development of self. Spirituality and self.

\section{LITERATURE REVIEW}

According to the Michel Armstrong, "Training is systematic development of the knowledge, skills and attitudes required by an individual to perform adequately a given task or job". (Source: A Handbook of Human Resource Management Practice, Kogan Page, 8th Ed.,2001)

According to the Edwin B Flippo, "Training is the act of increasing knowledge and skills of an employee for doing a particular job.” (Source: Personnel Management, McGraw Hill; 6th Edition, 1984)

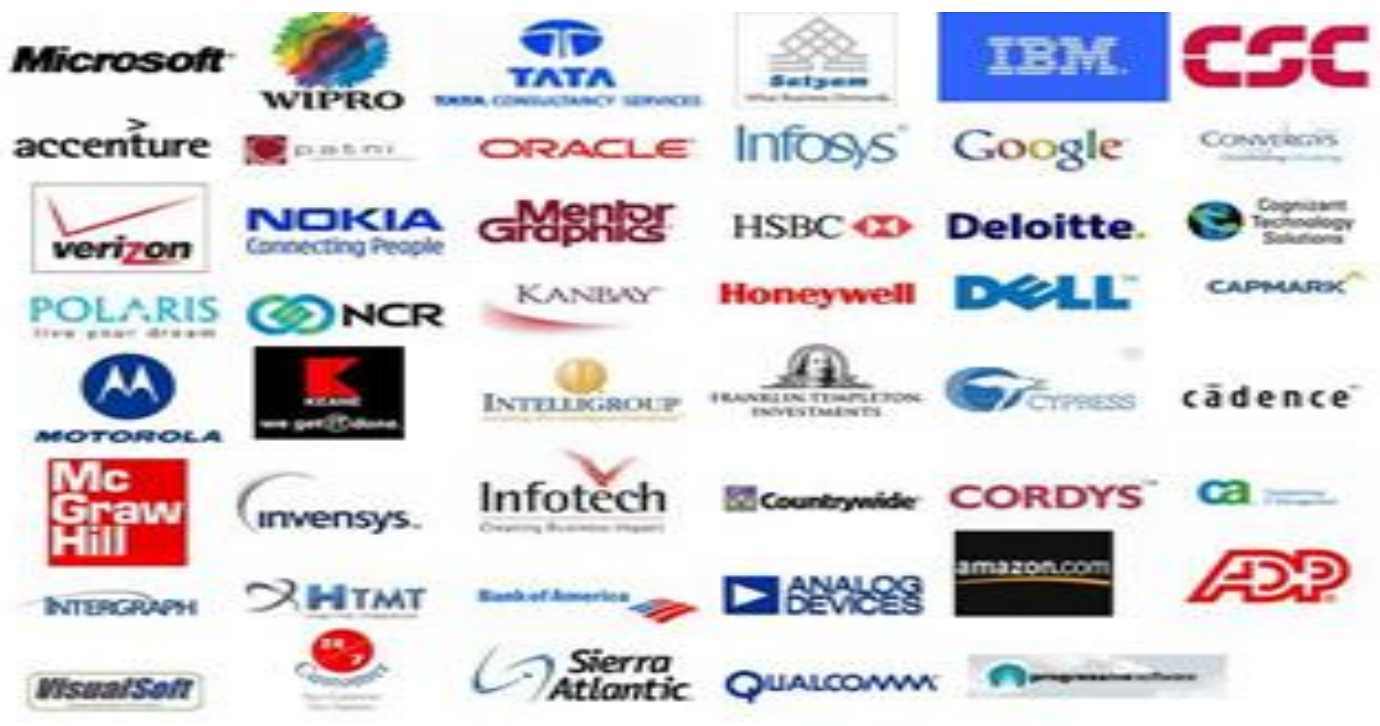

The principal objective of training is to make sure the availability of a skilled and willing workforce to the organization.

In addition to that, there are four other objectives:

1. Individual,

2. Organizational,

3. Functional, and

4. Social.

Opinions of different authors regarding Training \& Development

The term trainingee indicates the process involved in improving the aptitudes, skills and abilities of the employees to perform specific jobs. Training helps in updating old talents and developing new ones. „Successful candidates placed on the jobs need training to perform their duties 
effectively".(Source:Aswathappa, K. Human resource and Personnel Management, New Delhi: Tata Mcgraw-Hill Publishing CompanyLimited,2000, p.189)

Consider an MNC like Infosys. Infosys is that the second-largest Indian IT services company by 2016 revenues, and therefore the largest employer of H-1B visa professionals within the US. On January 12, 2017, its market capitalization was $\$ 34.38$ Billion Infosys Limited formally Infosys Technologies is an Company Profile Indian global technology services company headquartered in Bangalore. Infosys is ranked 27 within the list of top companies of India in Fortune India 500 list in 2011. It's offices in 29 countries and development centers in many Infosys had 145,088 employees of 85 countries.

Nationalities as on Infosys provides business New Year's Eve, 2011. consulting, technology, engineering and outsourcing services to assist clients in over 30 countries Vision \& Vision is to be a globally respected corporation Mission that gives best-of-breed business solutions, leveraging technology, Mission Statement is to realize delivered by best-in-class people their objectives in an environment of fairness, honesty, and courtesy towards their clients, employees, vendors and society at large SERVICES Aerospace and Automotive Banking and Capital Markets Communication Service Providers Energy and Utilities Healthcare Insurance Life Sciences Manufacturing Media and Entertainment Retail and Consumer grocery Services Transportation and Services.

Also there are many authors who shared their opinions on training and development.

"Transitioning new hires into your company has multiple cascading events that take place over time- for the leader, for the new hire, and the organization. Much more than merely enrolling people in benefits and setting up their payroll, it's your first chance to make a good impression and truly integrate the individual into your culture."(source:- 75 Ways for Managers to Hire, Develop, and Keep Great Employees by Paul Falcone 2021)

\section{III.METHODOLOGY AND TRAINING PROCESS}

Instructor-led training is the traditional type of employee training that occurs in a classroom, with a teacher presenting the material. This can be a highly effective method of employee training, especially for complex topics. Instructors can answer specific employee questions or direct them to further resources. There are 3 types of training methodologies as shown in below picture. 


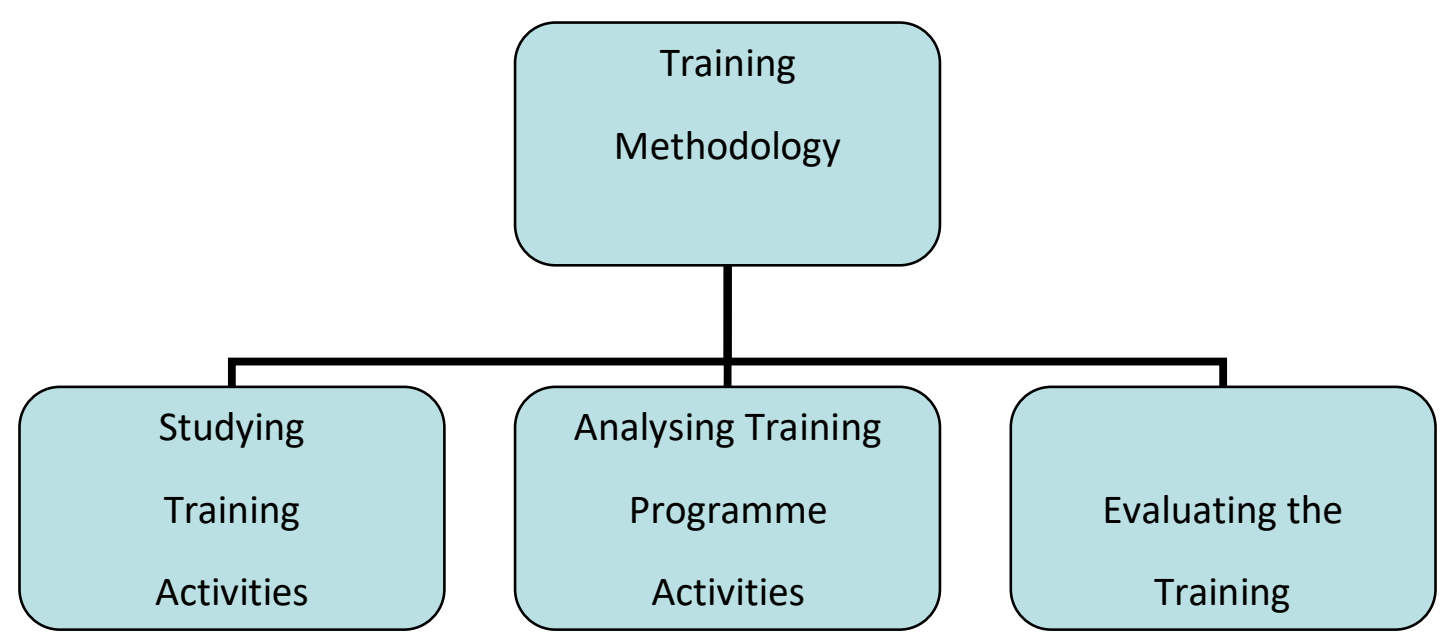

\section{Studying training activities:}

Training activity is the term for any planned undertaking that improves a learner's qualifications, knowledge or expertise. For that we have the following activities:

1. Role play: our brains are wired to learn through storytelling, and role-play scenarios are the best way to recreate the immersive environment that storytelling provides. Role-play is an active learning technique in which two or more trainees act out predetermined scenes under the guidance of an expert/trainer.

2. Discussion activities: These activities allow for more reflection, interaction, and thoughtful expression. The discussion method allows everyone to share their ideas. It gives time for learners to reflect on their own thoughts as well as learn about the perspective of others before sharing out loud.

3. Games: Game-like materials are also far more interactive than many traditional forms of training, like tests and quizzes, allowing users to learn through active practice and to review the content to increase their knowledge, skills and confidence through repeated practice.

4. E-training: eLearning, or electronic learning, is the delivery of learning and training through digital resources. This makes it easy for users to learn anytime, anywhere, with few, if any, restrictions. Basically, eLearning is training, learning, or education delivered online through a computer or any other digital device.

\section{Some other training methods:}

1. Panel

2. Demonstration

3. Seminar

4. Lecture

5. Conference

6. Self-Discovery

7. Simulations

8. Case Studies 
9. Mentoring

10. On-the-job training

11. Off-the-job training

\section{Analysing training programme activities:}

Training needs analysis is a systematic process of identifying which kind of training is required and provide the details related to training implementation. It is also known as a tool to identify the new skills, knowledge and attitudes which employees need to acquire in order to improve performance. There are 3 types of analysis:

1. Person need analysis: In industrial and organizational settings, a component of needs assessment in which data are collected to determine whether employees need training, which employees need training, and whether they are ready for training is termed as person need analysis. We will do the person need analysis in order to define the desired performance, determine the gap between desired and actual performance, identify the obstacles to effective performance.

2. Organizational need analysis: An Organisational Needs Analysis is an effective way to identify skills gaps. It involves gathering information to identify areas where your employees can improve their performance to their benefit and that of your business. The whole idea of Organizational need analysis is to benefit the organization by analysing the needs of employee during the training.

3. Job need analysis: The main purposes of conducting a job analysis process is to use this particular information to create a right fit between job and employee, to assess the performance of an employee, to determine the worth of a particular task and to analyze training and development needs of an employee delivering that specific job.

By using the above analysis, we can improve the methods of training \& development in an MNC.

\section{Person need analysis}

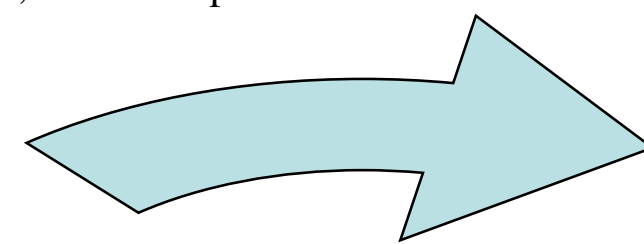
need analysis

\section{Job needs analysis.}

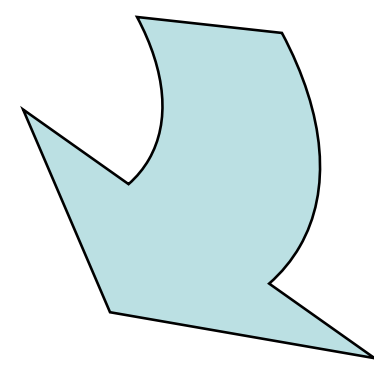




\section{Evaluation Process:}

\section{Performance Development Plan:-}

A sheet which the employee and manager has to fill where both of them have to provide information which all areas the employee has improved in.

\section{Projects:-}

Small term projects like on Six Sigma, where at the end of it the employee has to give presentations to the training team.

\section{Questionnaire:-}

Feedback from the employees on the quality and content of training Analysis is done on it and then it is scaled.

\section{CONCLUSION:}

Training and development is vital aspect in every organisation increase in competitiveness and advancement of technology leads need for training and development MNC's had adapted above training and development programmes to the worker to extend his standards in competitive world and reduce turnover rate within the company.

\section{VI.REFERENCES:}

X [1] P. Subba Rao (2009), "Essentials of Human Resource management and Industrial Relations", Himalaya Publication House, 3rd Revised \& Enlarged Edition.

X [2] Michel Armstrong (2001), “A Handbook of Human Resource Management Practice”, Kogan Page, $8^{\text {th }}$ Editon.

X [3] Mamoria, C. B. (1995), "Personnel Management (Management of Human resources)", Himalaya Publishing House, Bombay.

× C.K.Gomathy.(2010),"Cloud Computing: Business Management for Effective Service Oriented Architecture" International Journal of Power Control Signal and Computation (IJPCSC), Volume 1, Issue IV, Oct - Dec 2010, P.No:22-27, ISSN: 0976-268X .

X Dr.C K Gomathy, Article: A Study on the recent Advancements in Online Surveying, International Journal of Emerging technologies and Innovative Research ( JETIR ) Volume 5 | Issue 11 | ISSN : 2349-5162, P.No:327-331, Nov-2018

X Dr.C.K.Gomathy,C K Hemalatha, Article: A Study On Employee Safety And Health Management International Research Journal Of Engineering And Technology (Irjet)- Volume: 08 Issue: 04 | Apr 2021 
X Dr.C K Gomathy, Article: A Study on the Effect of Digital Literacy and information Management, IAETSD Journal For Advanced Research In Applied Sciences, Volume 7 Issue 3, P.No-51-57, ISSN NO: 2279-543X,Mar/2018

× Dr.C K Gomathy, Article: An Effective Innovation Technology In Enhancing Teaching And Learning Of Knowledge Using Ict Methods, International Journal Of Contemporary Research In Computer Science And Technology (Ijcrcst) E-Issn: 2395-5325 Volume3, Issue 4,P.No-10-13, April '2017

X Dr.C K Gomathy, Article: Supply chain-Impact of importance and Technology in Software Release Management, International Journal of Scientific Research in Computer Science Engineering and Information Technology ( IJSRCSEIT ) Volume 3 | Issue 6 | ISSN : 2456-3307, P.No:1-4, July2018 .

\section{AUTHOR'S PROFILE:}

1. Mr. CHANDRAMOULI SARAVAN SOWRI, 11199M009, Student, B.TECH Information Technology at SCSVMV, Enathur, Kanchipuram, India.

2. Mr. CHADA SESHA SAI ISWARYA BALARAM,11199M008,Student, B.TECH Information Technology at SCSVMV, Enathur, Kanchipuram, India.

3. Mr. L. M. Aravind, 11199M006, Student, B.TECH Information Technology at SCSVMV, Enathur, Kanchipuram, India.

4. Dr. C. K. GOMATHY Assistant Professor, Department of Computer Science and Engineering at SCSVMV, Enathur, Kanchipuram, India. 